\title{
A Research of Technology Adoption in Small and Medium-sized Enterprises in Yogyakarta
}

\author{
Fauziyah, Winarso, Andimi Hana Syarifah
}

\begin{abstract}
This study compares the impact of different size of SMEs and the age of SMEs on the technology adoption. This survey was conducted on the use of IT in SMEs in Yogyakarta, Indonesia. As a developing country, most of the Indonesian economy is dominated by SMEs. One factor that plays an important role in increasing the competitiveness of SMEs is information technology (IT) adoption. However, not all SMEs have similarities in their efforts to adopt IT. The theory underlying the process of adopting information technology is the Technology Acceptance Model (TAM). TAM have 3 main variables. There are Perceived Ease of Use, Perceived usefulness and Acceptance of IT. In this study analyzed differences in IT adoption based on the age of SMEs and the SME category (micro, small and medium). This study also examined differences based on competitive advantage. The results show that there are no significant differences in IT acceptance based on the age of SMEs and they have similarities in competitive advantage. The results of this study provide benefits for SMEs to evaluate their adoption of technology. In addition, this research is also beneficial for the government to develop SMEs in the region. Keywords: Adoption of IT, TAM, Competitive advantage, SMEs.
\end{abstract}

Index Terms-Adoption of IT,Competitive advantage, SMEs, TAM

\section{INTRODUCTION}

The development of SMEs in Indonesia has recently increased sharply. This indicates the welfare of the community and the sustainability of the economy. SMEs contribute greatly to the country's economy. This development occurs in almost all regions in Indonesia. Especially in Yogyakarta which has a very rapid development of SMEs.

Based on data presented by the Central Bureau of Statistics (BPS), 90\% - 95\% of companies in Indonesia are classified as SMEs. The statistical information shows that Indonesian economy is supported by the existence of SMEs' activity (Nugrohoet.al, 2017).According to data released by McKensey and Company, a global management consulting agency in Indonesia, Indonesia's economy will be boosted by $10 \%$ through digital activities in 2025 . Through a digital technology approach, the country has the opportunity to create 3.7 million new jobs, including job matching schemes and labor demand through online based platforms.Therefore, the government encourages the SMEs sector to use digital platforms in their business processes. However, not all SMEs immediately follow up on this. New emerging SMEs are usually dominated by young people who are very familiar with the digital world. Even since its inception, they

Revised Manuscript Received on August 05, 2019.

Fauziyah, UniversitasMuhammadiyah Yogyakarta,Indonesia. (Email: Fauziyah@umy.ac.id)

Winarso, UniversitasMuhammadiyah Yogyakarta,Indonesia. (Email: Winarso@umy.ac.id)

Andimi Hana Syarifah, UniversitasMuhammadiyah Yogyakarta,Indonesia. (Email: hannahunny82@gmail.com) have used digital technology. While SMEs that have long been established are usually owned by old people who are not familiar with technology so they do not directly adopt the technology.

ICTs adoption by SMEs is influenced by many factors which have compelled SMEs to adopt ICTs for survival growth, sustainability and competitiveness (Ongori \& Migiro, 2011). There are size, age of SMEs, the kind of business etc. So, in this study there will be a different test analysis of SMEs in adopting IT based on the size and age of SMEs. The study conducted by Sharma and Bhagwat, (2006) demonstrated that the flow of information in an organisation is the backbone of any business operational unit irrespective of its size. In addition, size of business is a matter that needs to be considered.

The variables used in this study refer to the TAM theory proposed by Davis (1989) which consists of perceived ease of use, perceived usefulness and IT acceptance. Besides that, it also added competitive advantage variables to understand their perceptions of IT adoption for competition.

\section{LITERATUR REVIEW}

\section{A. Perceived Ease of Use}

Perceived ease of use refer to the degree to which a person believes that using a particular system would be free of effort (Davis, 1989). An application perceived to be easier to use than another is more likely to be accepted by users.

\section{B. Perceived Usefulness}

Perceived usefulness is defined here as the degree to which a person believes that using a particular system would enhance his or her job performance (Davis, 1989). Based on these definitions, it can be interpreted that the benefits of using computers can improve performance, as well as the work performance of people who use it.

\section{IT Acceptance}

Pebruati et al. (2013) stated that individually and collectively the use of revenue can be explained from the variation in the use of a system because it is believed that the use of an IT-based system can develop individual performance or organizational performance.

\section{Competitive Advantage}

The concept of competitive advantage lies at the heart of understanding a firm's performance in competitive markets; above average performance in the long-run can only be generated by creating a sustainable competitive advantage (Porter, 2004).

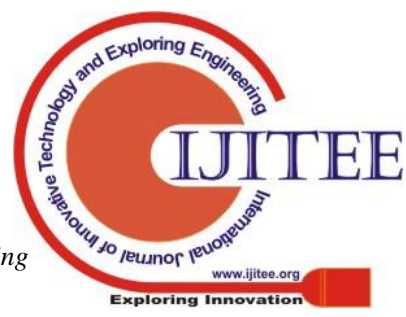




\section{RESEARCH METHOD}

\section{A. Data collection and Sampling}

The questionnaire was distributed directly to $116 \mathrm{SME}$ owners in Yogyakarta to get their response regarding IT adoption in their business. The data used is primary data. SMEs in this research will be categorized into micro, small and medium based on their assets and annual sales. The SME category is based on criteria in accordance with Indonesian Law No. 20 Year 2008. Micro businesses have a net asset of less than 50 million - and annual sales are less than 300 million years. Small businesses have net assets of more than 50 million and annual sales between 300 million 2.5 billion per year, and medium businesses have net assets of 500 million - 10 billion / year and annual sales of 2.5 billion - 50 billion / year.

\section{B. Variable Measurements}

Perceived ease of use is measured through indicators, [1] ease to learn, [2] controllable, [3] clear and understable, [4] flexible, [5] improved skills, and [5] easy to use.

Perceived usefulness can be measured through indicators [1] work becomes faster, [2] useful, [3] increases productivity, [4] increases effectiveness, and [5] improves performance. Indicator of perceived ease of use and perceived usefulness modified from Davis (1989).

According to Natalia (2014), IT acceptance is measured by indicators [1] user satisfaction, [2] usability of the system and [3] intensity of use.

The perceived competitive advantage after the use of IT in UKM is measured through indicators [1] timeliness, [2] price, [3] product innovation, [4] quality, [5] time to market.This indicator is modified from the indicators used by Oktavia (2014)

\section{Data Analysis Method}

Before conducting the compare means test, the data distribution was tested first with the Kolmogorov Smirnov test to determine the right tool. The size and the age of business were investigated using the Kruskal Wallis Test

\section{DATA ANALYSIS AND RESULTS}

\section{A. Demographics of the respondents}

The demographic of respondents will describe below.

Table 1 Demographic of Respondents

\begin{tabular}{|l|l|l|}
\hline Item & Frequency & Percent \\
\hline Gender & & \\
\hline Male & 61 & 52.6 \\
\hline Female & 55 & 47.4 \\
\hline Total & $\mathbf{1 1 6}$ & $\mathbf{1 0 0}$ \\
\hline Age & & \\
\hline $21-30$ years & 18 & 15.5 \\
\hline $31-40$ years & 35 & 30.2 \\
\hline Over 40 years & 63 & 54.3 \\
\hline Total & $\mathbf{1 1 6}$ & $\mathbf{1 0 0}$ \\
\hline Education Level & & \\
\hline Elementary School & 2 & 1.7 \\
\hline Junior High School & 13 & 11.2 \\
\hline Senior High School & 51 & 44 \\
\hline Diploma & 2 & 1.7 \\
\hline Undergraduate & 27 & 23.3 \\
\hline Graduate & 3 & 2.6 \\
\hline Unknown & 18 & 15.5 \\
\hline Total & $\mathbf{1 1 6}$ & $\mathbf{1 0 0}$ \\
\hline
\end{tabular}

Based on the respondents' demographics, it can be seen that the majority of SMEs are male, over 40 years old with senior high school education.

\section{B. SMEs profile}

SMEs are categorized into micro, small and medium. SMEs will also be characterized based on the age of their business. The profile of SMEs is presented in Table 2.

Table 2 SMEs Profile

\begin{tabular}{|l|l|l|}
\hline Item & Frequency & Percent \\
\hline Size of SMEs & & \\
\hline Micro & 74 & 63.8 \\
\hline Small & 39 & 33.6 \\
\hline Medium & 3 & 2.6 \\
\hline Total & $\mathbf{1 1 6}$ & $\mathbf{1 0 0}$ \\
\hline Age of SMEs & & \\
\hline $0-5$ years & 35 & 30.2 \\
\hline $6-10$ years & 49 & 42.2 \\
\hline $11-15$ years & 21 & 18.1 \\
\hline $16-20$ years & 10 & 8.6 \\
\hline Over 20 years & 1 & 0.9 \\
\hline Total & $\mathbf{1 1 6}$ & $\mathbf{1 0 0}$ \\
\hline
\end{tabular}

\section{Validity and Reliability Testing}

This study uses Product Moment Pearson to test item validity and Cronbach alpha to test the reliability of the items. Based on the validity test it is known that ACC3 is the only item that does not meet the requirements. ACC3 is an indicator of acceptance of IT. This item measure IT usage on every working day. Therefore ACC 3 was excluded from the analysis. Thus all items used in this study have met validity and reliability test.

\section{Descriptive Statistic of Variables}

Before presenting the descriptive statistics, a table of mean and category will be displayed in the table below.

Table 3 Mean and Category

\begin{tabular}{|l|l|}
\hline Mean & Category \\
\hline $1.0-1.79$ & Very low \\
\hline $1.8-2.59$ & Low \\
\hline $2.6-3.39$ & Medium \\
\hline $3.4-4.19$ & High \\
\hline $4.2-5.00$ & Very high \\
\hline
\end{tabular}

Table 4 will present descriptive statistics based on the variables in TAM and competitive advantage. Based on the Table 4, almost all indicators are in the high category except CA3 which is in the medium category. CA3 is CA3 stating that by using IT, product innovation can be done. This result shows that IT adoption by SMEs has not been used for strategic purposes, but is only used for administrative purposes. 
Table 4 Descriptive Statistic of Variables

\begin{tabular}{|l|l|l|}
\hline Variable & Mean & Category \\
\hline PEOU1 & 3.67 & High \\
\hline PEOU2 & 3.71 & High \\
\hline PEOU3 & 3.62 & High \\
\hline PEOU4 & 3.61 & High \\
\hline PEOU5 & 3.57 & High \\
\hline PEOU6 & 3.61 & High \\
\hline Grand Mean & $\mathbf{3 . 6 3}$ & High \\
\hline PU1 & 4.03 & High \\
\hline PU2 & 4.10 & High \\
\hline PU3 & 4.07 & High \\
\hline PU4 & 4.00 & High \\
\hline PU5 & 3.90 & High \\
\hline Grand Mean & $\mathbf{4 . 0 0}$ & High \\
\hline ACC1 & 3.66 & High \\
\hline ACC2 & 4.18 & High \\
\hline Grand Mean & $\mathbf{3 . 9 2}$ & High \\
\hline CA1 & 3.47 & High \\
\hline CA2 & 3.41 & High \\
\hline CA3 & 3.34 & Medium \\
\hline CA4 & 3.73 & High \\
\hline Grand Mean & $\mathbf{3 . 4 9}$ & High \\
\hline & & \\
\hline
\end{tabular}

\section{E. Prerequisite Test}

Before conducting compare means test, it's necessary to having prerequisite test to evaluate data distribution using normality test. The test used is Kolmogorov-Smirnov value. Following are the results of the Kolmogorov-Smirnov test.

Table 5 Kolmogorov-Smirnov Test Hypothesis Test Summary

\begin{tabular}{|c|c|c|c|c|}
\hline & Null Hypothesis & Test & Sig. & Decision \\
\hline 1 & $\begin{array}{l}\text { The distribution of PEOU is normal } \\
\text { with mean } 21,793 \text { and standard } \\
\text { deviation } 2,70 \text {. }\end{array}$ & $\begin{array}{l}\text { One-Sample } \\
\text { Kolmogorov- } \\
\text { Smirnov Test }\end{array}$ &, $000^{1}$ & $\begin{array}{l}\text { Reject the } \\
\text { null } \\
\text { hypothesis. }\end{array}$ \\
\hline 2 & $\begin{array}{l}\text { The distribution of PU is normal with } \\
\text { mean } 20,191 \text { and standard deviation } \\
1,46 \text {. }\end{array}$ & $\begin{array}{l}\text { One-Sample } \\
\text { Kolmogorov- } \\
\text { Smirnov Test }\end{array}$ &, $000^{1}$ & $\begin{array}{l}\text { Reject the } \\
\text { null } \\
\text { hypothesis. }\end{array}$ \\
\hline 3 & $\begin{array}{l}\text { The distribution of ACC is normal } \\
\text { with mean } 7,853 \text { and standard } \\
\text { deviation } 1,05 \text {. }\end{array}$ & $\begin{array}{l}\text { One-Sample } \\
\text { Kolmogorov- } \\
\text { Smirnov Test }\end{array}$ &, $000^{1}$ & $\begin{array}{l}\text { Reject the } \\
\text { null } \\
\text { hypothesis. }\end{array}$ \\
\hline 4 & $\begin{array}{l}\text { The distribution of CA is normal with } \\
\text { mean } 13,922 \text { and standard deviation } \\
2,17 \text {. }\end{array}$ & $\begin{array}{l}\text { One-Sample } \\
\text { Kolmogorov- } \\
\text { Smirnov Test }\end{array}$ &, $000^{1}$ & $\begin{array}{l}\text { Reject the } \\
\text { null } \\
\text { hypothesis. }\end{array}$ \\
\hline
\end{tabular}

Asymptotic significances are displayed. The significance level is ,05.

These results indicate that the data is abnormally distributed, so that the compare mean test used is the Kruskal Wallis test.

\section{F. Kruskal Wallis Test.}

The following are the compare mean test results based on the size and age of the SMEs with the Kruskal Wallis test.

The results show that size is not a determinant of IT adoption. No matter size of the SMEs, they have the same perception in ease of use, usefulness, IT acceptance and competitive advantage. This breaks the assumption that the larger the size of the company, the greater the level of IT adoption.The rapid development of IT in all fields makes IT a necessity for all businesses, even for small-scale businesses. Almost all business processes are supported with IT that provides various benefits and conveniences.

Table 6 Kruskal Wallis Test Result based on Size Hypothesis Test Summary

\begin{tabular}{|c|c|c|c|c|}
\hline & Null Hypothesis & Test & Sig. & Decision \\
\hline 1 & $\begin{array}{l}\text { The distribution of PEOU is the } \\
\text { same across categories of Size. }\end{array}$ & $\begin{array}{l}\text { Independent- } \\
\text { Samples } \\
\text { Kruskat- } \\
\text { Wallis Test }\end{array}$ & .175 & $\begin{array}{l}\text { Retain the } \\
\text { null } \\
\text { hypothesis. }\end{array}$ \\
\hline 2 & $\begin{array}{l}\text { The distribution of PU is the same } \\
\text { across categories of Size. }\end{array}$ & $\begin{array}{l}\text { Independent- } \\
\text { Samples } \\
\text { Kruskat. } \\
\text { Wallis Test }\end{array}$ & .068 & $\begin{array}{l}\text { Retain the } \\
\text { null } \\
\text { hypothesis. }\end{array}$ \\
\hline 3 & $\begin{array}{l}\text { The distribution of } A C C \text { is the same } \\
\text { across categories of Size. }\end{array}$ & $\begin{array}{l}\text { Independent- } \\
\text { Samples } \\
\text { Kruskat } \\
\text { Wallis Test }\end{array}$ & .133 & $\begin{array}{l}\text { Retain the } \\
\text { null } \\
\text { hypothesis }\end{array}$ \\
\hline 4 & $\begin{array}{l}\text { The distribution of } \mathrm{CA} \text { is the same } \\
\text { across categories of Size. }\end{array}$ & $\begin{array}{l}\text { Independent- } \\
\text { Samples } \\
\text { Kruskal } \\
\text { Wailis Test }\end{array}$ & .375 & $\begin{array}{l}\text { Retain the } \\
\text { null } \\
\text { hypothesis }\end{array}$ \\
\hline
\end{tabular}

Asymptotic significances are displayed. The significance level is, 05 .

Table 7 Kruskal Wallis Test Result based on Age of SMEs Hypothesis Test Summary

\begin{tabular}{|c|c|c|c|c|}
\hline & Null Hypothesis & Test & Sig. & Decision \\
\hline 1 & $\begin{array}{l}\text { The distribution of PEOU is the } \\
\text { same across categories of Age. }\end{array}$ & $\begin{array}{l}\text { Independent- } \\
\text { Samples } \\
\text { Kruskal- } \\
\text { Wallis Test }\end{array}$ &, 455 & $\begin{array}{l}\text { Retain the } \\
\text { null } \\
\text { hypothesis. }\end{array}$ \\
\hline 2 & $\begin{array}{l}\text { The distribution of } \mathrm{PU} \text { is the same } \\
\text { across categories of Age. }\end{array}$ & $\begin{array}{l}\text { Independent- } \\
\text { Samples } \\
\text { Kruskal- } \\
\text { Wallis Test }\end{array}$ &, 511 & $\begin{array}{l}\text { Retain the } \\
\text { null } \\
\text { hypothesis. }\end{array}$ \\
\hline 3 & $\begin{array}{l}\text { The distribution of ACC is the same } \\
\text { across categories of Age. }\end{array}$ & $\begin{array}{l}\text { Independent- } \\
\text { Samples } \\
\text { Kruskal- } \\
\text { Wallis Test }\end{array}$ & ,190 & $\begin{array}{l}\text { Retain the } \\
\text { null } \\
\text { hypothesis. }\end{array}$ \\
\hline 4 & $\begin{array}{l}\text { The distribution of CA is the same } \\
\text { across categories of Age. }\end{array}$ & $\begin{array}{l}\text { Independent- } \\
\text { Samples } \\
\text { Kruskal- } \\
\text { Wallis Test }\end{array}$ &, 104 & $\begin{array}{l}\text { Retain the } \\
\text { null } \\
\text { hypothesis. }\end{array}$ \\
\hline
\end{tabular}

Asymptotic significances are displayed. The significance level is ,05.

Based on Table 6 and Table 7, it can be seen that both based on the size of the SMEs, as well as the age of the business, there is no significant difference between perceived ease of use, perceived usefulness, technology acceptance and competitive advantage. This shows that IT adoption has been believed to be easy and useful so that they accept the technology. They also believe that the use of technology will increase competitiveness. Both micro, small and medium sized businesses have the same perception. Thus the proposed hypothesis is rejected.

\section{FINDINGS AND DISCUSSION}

Based on the results above, it shows that there is no difference between perceived ease of use, perceived usefulness, IT acceptance and competitive advantage based on business size and age. This shows that the need for technology has been felt by all SME actors both on the micro, small and medium scale. This proves that all SMEs

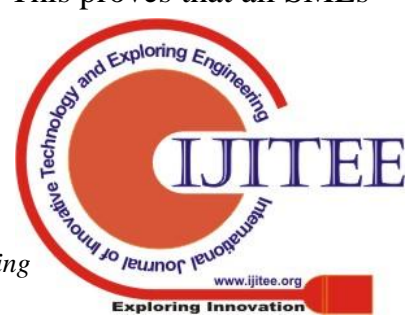


with different sizes and ages of SMEs both recognize that IT is easy to use and provides many benefits for SMEs. Therefore their IT acceptance rates are high. Besides that they believe that their competitive advantage is increasing with the use of IT. This is in accordance with the findings of Tarute and Gatautis (2013) that ICT adoption can improve performance, including competitiveness.

The results of this study are in accordance with the findings of the study by Ramdani and Kawalek (2007) who stated that the adoption of ES does not strongly depend on company size. There are many other factors that influence the level of IT adoption, such as level of understanding, price, infrastructure etc.

The important thing to note in this study is that the CA3 level is still in the moderate category. CA3 states that by using IT, product innovation can continue. This shows that IT use is needed by SMEs but its use is not for strategic purposes.

Some of the SMEs that already have computers, not many have used it for strategic and external oriented activities. Referring to the IT adoption scenario, most SMEs in Indonesia are at level 0 or 1 . This is supported by data that as many as $68.9 \%$ of SMEs use computers only to type letters or reports, $66.67 \%$ to do calculations, $34.5 \%$ for accessing the Internet, $43.7 \%$ for product design, $28.7 \%$ for running information systems, and $20.7 \%$ for conducting business presentations.

It should be noted that SMEs' confidence in adopting IT needs to be assessed in the realization of its use. Because their perception of IT is not necessarily accompanied by the use of IT in real terms in their business. This is in accordance with the results of research conducted by Nugrohoet. al (2017) which states that not each of business entity is going to use information technologies even they state that the importance of adopting information technology briefly.

\section{LIMITATIONS AND FUTURE RESEARCH}

In this study, we still need to explore more about the benefits of IT for competitive advantage. Research on how much influence the use of IT has on their level of competitiveness is needed. Besides that, it is necessary to do research on what types of IT they use in their business processes. Further research needs to be done to analyze the role of IT in business whether for strategic purposes or just for administrative purposes.

SMEs have believed in the importance of IT, therefore the role of government is needed to improve the skills of business people in using IT and open their eyes to the diversity of IT that can provide strategic benefits for SMEs.

\section{REFERENCES}

1. Davis, F.D., "Perceived usefulness, perceived ease of use and user acceptance of information Tecnology," MIS Quarterly, vol 13; 3, pp 319-340, Sep. 1989

2. Davis, F.D., Bagozzi, R.P., Warshaw, P.R., "User acceptance of computer technology: a comparison of two theoritical Models,' Management Science, vol. 35, 8, pp.982-1003, Aug 1989

3. Nugroho, M.A., Susilo, A.Z., Fajar, M.A., Rahmawati, D., "Exploratory Study of SMEs Technology Adoption Readiness

4. Factors," Procedia Computer Science, 124, pp. 329-336, 2017
5. Oktavia, P. N., "AnalisisDampak Servant Leadership terhadap Competitive Advantage", Business Accounting Review, vol.2(2), pp. 244-251, 2014

6. Ongori, H., Migiro, S.O., "Understanding the drivers of information and communication technologies (ICTs) adoption by Kenyansmall and medium enterprises (SMEs),"International Journal of Management Research And Revie, vol. 1 issue 1, Aug. 2011

7. Pebruati.S.,Handayani S.R., "Pengaruhaplikasiteknologiinformasidalampeningkatandayasaingperu sahaan" Jurnal Profit, vol.7 no. 1, pp 62-75. 2012

8. Porter. M.E., Competitive advantage: creating and sustaining superior performance, (Revised edition), The Free Press, 2004

9. Ramdani, B., Kawalek, P., "SMEs \& IS innovations adoption: A review \& assessment of previous research," Academia, Revista Latinoamericana de Administración, 39, pp. 47-70, 2007

10. Sharma M.K. \&Bhagwat.R. "Practice of information systems, an evidence from select Indian SMEs," Journal of Manufacturing Technology, vol.17 (2), pp. 199-223, 2006

11. Natalia, T., "AnalisaPenerimaanPenerapanTeknik Audit BerbantuanKomputer (TABK) denganMenggunakan Technology Acceptance Model (TAM) padaBadanPemeriksaKeuangan (BPK) RI," JurnalAkuntansi\&Keuangan, vol. 6, No. 1, pp. 10-28, May 2004

12. Tarute, A., Gatautis, R., "ICT impact on SMEs performance," Procedia - Social and Behavioral Sciences 110, pp. 1218 - 1225, 2014

\section{Appendix}

\section{The list of items:}

Perceived Ease of Use (PEOU)

1. $\mathrm{T}$ is easy to learn

2. IT can be controlled easily

3. IT is clear and easy to understand

4. IT is flexible and can be adapted to the conditions of SMEs

5. My skills are increasing when I use IT

6. IT is easy to use.

Perceived Usefulness

1. IT accelerates the completion of work

2. IT is useful in supporting business activities

3. IT can increase work productivity

4. IT increases work effectiveness

5. IT can improve the performance of SMEs

IT Acceptance

1. I feel satisfied when using IT

2. I am willing to use IT to support my business activities

3. I use IT on every working day.

Competitive Advantage

1. Work can be completed on time

2. I can compare prices with competitors

3. By using IT, product innovation can be done continuously

4. IT is able to introduce my new product to consumers 